\title{
EXEMPTION PROVISIONS AND THE CONSUMER PROTECTION ACT, 2008: SOME PRELIMINARY COMMENTS
}

\section{Introduction}

Suppliers have found it most convenient to reduce their risk of liability by inserting a provision in their contracts with consumers - be it in a written and signed contract or in the form of a displayed notice - in terms of which suppliers are exempted from liabilities they would otherwise be obliged to accept (Christie and Bradfield Christie's The Law of Contract in South Africa (2011) 191). Exemption of liability provisions are often contained in standard-form contracts but also in notices displayed at public venues such as hotels, restaurants, shopping malls, parking garages, entertainment complexes, tourist attractions and even petrol-service stations (see Maxwell "Obligations and Terms" in Hutchison and Pretorius The Law of Contract in South Africa (2012) 240. In fact, the SCA, in Afrox Healthcare (Pty) Ltd v Strydom 2002 (6) SA 21 (SCA) 34E, remarked that exemption provisions have become the rule rather than the exception in standard-form contracts used by hospitals (see also Christie and Bradfield Christie's The Law of Contract in South Africa 190)). The same may probably be said of a host of other suppliers, including suppliers of tourism services. It is not surprising, therefore, that a significant factor in the development of consumer law in general can be "ascribed to legislative responses to business disclaimers of accountability for negative consequences attendant upon their dealings with consumers" (Van Eeden A Guide to the Consumer Protection Act (2009) 4).

The Consumer Protection Act 68 of 2008 (CPA) introduced a number of provisions which impact on the use by suppliers of provisions that aim to exclude the liability of suppliers for harm to consumers caused through the negligence of the supplier. The CPA defines a supplier in section 1 as: "a person who markets any goods or services". To market is defined as: "to promote or supply any goods or services" (s 1).

This note seeks to provide a conceptual framework for the understanding and application of relevant provisions of the CPA to exemption provisions. The impact is considered within the context of the tourism industry in order to illustrate some of the practical consequences of the CPA on the use of exemption provisions. The note does not seek to question whether exemption provisions are contrary to public policy per se. (For more on this issue, see Marx and Govindjee "Revisiting the Interpretation of Exemption Clauses - Drifters Adventure Tours CC v Hircock 2007 (2) SA 83 (SCA)" 2007 Obiter 622 and the sources listed therein, as well as Naudé and Lubbe "Exemption Clauses - A Rethink Occasioned by Afrox Healthcare Bpk v Strydom" 2003 SALJ 441.) 


\section{The common law and exemption provisions}

Fundamental to the South African common law of contract are the principles of freedom of contract (party autonomy) and pacta sunt servanda (sanctity of contract). Parties are free to negotiate the terms of their agreement and once agreement has been reached, the contract must be honoured and, if necessary, enforced by the courts. Whether agreement has been reached is determined with reference to the requirements of consensus and reasonable reliance as the two bases for establishing a contract in South African law.

Exemption provisions are often contained in standard-form contracts which are "contracts that are drafted in advance by the supplier of goods or services and presented to the consumer on a 'take-it-or-leave-it' basis" (Sachs J in Barkhuizen v Napier 2007 (7) BCLR 691 (CC) par 135). Probably because there is little perceived practicality in attempting to resist the terms of a standard-form contract, or because the terms are couched in obscure legalese and hidden in the fine print of the contract, most consumers simply sign or accept the contract without necessarily knowing about the presence of the exemption provisions or without appreciating the implications of signing such a contract (see Barkhuizen $v$ Napier supra par 135-136). The consequence of such an action is that the caveat subscriptor rule will apply, and the party signing without reading or understanding the contract will be bound to it. The basis for such contractual liability is that by signing the contract the party has created the impression in the mind of the supplier that consensus was indeed reached (Christie and Bradfield Christie's The Law of Contract in South Africa 181-186; Pretorius "Mistake/Absence of Consensus" in Hutchison and Pretorius The Law of Contract in South Africa (2012) 97; Otto "A Consumer's Right to Plain Language and to be informed in an Official Language that he understands as required by the National Credit Act - Standard Bank of South Africa Ltd $v$ Dlamini 2013 (1) SA 219 (KZD)" 2014 THRHR 162-163; Pretorius "Exemption Clauses and Mistake - Mercurius Motors v Lopez 20082 SA 572 (SCA)" 2010 THRHR 492 and George v Fairmead (Pty) Ltd 1958 (2) SA 465 (A)). The caveat subscriptor rule is not absolute and a party who signed a contract without reading it may escape liability on the basis of iustus error. This could apply when, for instance, a contract contains an unusual term for that type of contract which the reasonable person would not expect to find there, or when the contract deviated from previous oral negotiations, or where the other party misrepresented the terms of the contract. A contracting party may escape liability also where the party signed the contract due to duress, undue influence or commercial bribery (Otto 2014 THRHR 162-163; Christie and Bradfield Christie's The Law of Contract in South Africa 184-186 and Maxwell in Hutchison and Pretorius The Law of Contract in South Africa 239).

Exemption provisions are found also in notices displayed by a supplier. Under the common law a consumer can be held to an exemption provision where the term is contained in a notice, provided that the consumer was aware of the notice or the supplier took reasonable steps to bring the notice to the attention of the consumer (see Durban's Water Wonderland $v$ Botha 1991(1) SA 982 (AD); Naidoo v Birchwood Hotel 2012 (6) SA 170 (GSJ) and Maxwell in Hutchison and Pretorius The Law of Contract in South Africa 
240-241. See also Christie and Bradfield Christie's The Law of Contract in South Africa 186-190). A party who wishes "to contract out of liability must do so in clear and unequivocal terms which are clearly visible" (Naidoo $v$ Birchwood Hotel supra par 40; and First National Bank of SA Ltd $v$ Rosenblum 2001 (4) SA 189 (SCA) par 6).

Therefore (provided that the exemption provision complies with the normal requirements for concluding a valid contract), contracts or terms excluding the liability of a party, as a general rule, are valid (Maxwell in Hutchison and Pretorius The Law of Contract in South Africa 240-241; Christie and Bradfield Christie's The Law of Contract in South Africa 190-199; Naidoo v Birchwood Hotel supra; Drifters Adventure Tours CC v Hircock 20071 All SA 133 (SCA); Johannesburg Country Club v Stott 2004 (5) SA 511 (SCA); Afrox Healthcare (Pty) Ltd $v$ Strydom supra 34D; Durban's Water Wonderland v Botha supra; and George v Fairmead (Pty) Ltd supra).The South African courts have enforced exemption agreements for harm caused negligently, and even for harm caused through gross negligence (see Loubser and Midgley The Law of Delict in South Africa (2009) 197).

Probably the main consideration for giving effect to exemption provisions was expressed by the Constitutional Court when it stated in Barkhuizen $v$ Napier (supra par 57) that:

"public policy, as informed by the Constitution, requires, in general, that parties should comply with contractual obligations that have been freely and voluntarily undertaken. This consideration is expressed in the maxim pacta sunt servanda, which, as the Supreme Court of Appeal has repeatedly noted, gives effect to the central constitutional values of freedom and dignity. Selfautonomy, or the ability to regulate one's affairs, even to one's own detriment, is the very essence of freedom and a vital part of dignity".

However, "[a]lthough legal, the courts have recognized the scourge which these provisions often are" and have developed different ways in which to limit the application in particular scenarios (Pretorius 2010 THRHR 491492).

Foremost, although public policy permits the use and enforcement of exemption provisions, it also imposes limits - and a party cannot exclude liability for fraudulent conduct (see Christie and Bradfield Christie's The Law of Contract in South Africa 191). A further factor that may in appropriate instances be used to limit the application of exemption provisions is the general rule that these provisions must be interpreted restrictively (Afrox Healthcare (Pty) Ltd v Strydom supra 34D; see also Christie and Bradfield Christie's The Law of Contract in South Africa 195-198; and Pretorius 2010 THRHR 491). In this regard, the contra proferentem rule can play a significant role to prefer an interpretation that favours the consumer where more than one reasonable interpretation of the exemption provision exists (see Drifters Adventure Tours CC v Hircock supra; and Vrancken and Tait "Southern Africa Can be a Tough Country for Tourism Service Providers ... Even with an Exemption Clause - Drifters Adventure Tours CC v Hircock 20071 All SA 133 (SCA)" 2008 Speculum Juris 139).

Despite these mechanisms for limiting the ambit of exemption provisions, Naudé and Lubbe (2003 SALJ 442) in the aftermath of Afrox Healthcare Bpk $\checkmark$ Strydom (supra) decision, lamented that "common-law devices for 
controlling exemption provisions are few in number and of limited scope." It is this situation that has caused many to argue for legislation to protect South African consumers against unfair contract terms (see Naudé "The Consumer's 'Right to Fair, Reasonable and Just Terms' under the New Consumer Protection Act in Comparative Perspective" 2009 SALJ 505 and the references which Naudé details in fn 1).

The courts also raised concerns about whether it was constitutional to use exemption provisions specifically for excluding liability for death or personal injury caused by the supplier. In Johannesburg Country Club v Stott (supra par 12), the SCA expressed an obiter view that "[i]t is arguable that to permit such exclusion [of liability for death or personal injury] would be against public policy because it runs counter to the high value the common law and, now, the Constitution place, on the sanctity of life." In Naidoo v Birchwood Hotel (supra par 44-45), the Court also expressed an obiter view that provisions excluding the liability of a party for negligently causing the death of another would, in all likelihood, not withstand a constitutional challenge. (It should be noted that in some foreign jurisdictions such as the United Kingdom, such a term is void in terms of section 2 of the Unfair Contract Terms Act 1977; see Woodroffe and Lowe Consumer Law and Practice (2007) 143; and see also Letzler "The Law of Contract, the Consumer Protection Act and Medical Malpractice Law" June 2012 De Rebus 23.)

\section{The CPA and exemption provisions}

The CPA came into effect generally on 1 April 2011. It contains a number of provisions controlling the use of exemption provisions in consumer agreements. Typically, different methods of control are used and these methods can be divided into different categories. The first category contains rules "that set threshold requirements for terms to be considered part of the contract in the first place" and these rules are referred to as incorporation tests or prerequisites (Naudé 2009 SALJ 506). Section 49 of the CPA contains tests of incorporation. These specify that an exemption provision must comply with certain formal requirements before it can become part of the contract between the supplier and the consumer.

The second category relates to the content of the actual term and this is referred to as substantive control or content control. In sections 48 and 51 of the CPA one finds content control measures in respect of exemption provisions. The last category is interpretational control which involves the rules and process of legal interpretation (Naudé 2009 SALJ 506). Ambiguous terms of contract generally will be interpreted against the drafter of the contract, who is usually the supplier of the goods or services, according to the contra proferentem rule which is incorporated in the CPA in section $4(4)(a)$. The primary focus of this note is on the first two categories.

\section{Tests of incorporation - section 49}

Section 49(1)(a) provides that:

"Any notice to consumers or provision of a consumer agreement that purports to 
(a) limit in any way the risk or liability of the supplier or any other person; must be drawn to the attention of the consumer in a manner and form that satisfies the formal requirements of subsections (3) to (5)."

The essence of section 49 is contained in subsection (1), which requires that an exemption provision in a consumer agreement must be drawn to the attention of the consumer. Section 49(3)-(5) provides for the manner in which the provision must be drawn to the attention of the consumer.

\section{The exemption provision must be in plain language}

Section 49(3) requires the provision to be in plain language. This requirement is echoed in section 50 (2)(b)(i) which states that, if a consumer agreement entered into between a consumer and a supplier is in writing, whether the writing is required by the Act or not, the agreement must be in plain language. To write in plain language is not as simple as it may sound (see Otto 2014 THRHR 162). This requirement justifies a discussion of its own which is not possible in the current context. (For more on this topic, see the discussion by De Stadler Consumer Law Unlocked (2013) 104-112; see also Newman "The Application of the Plain and Understandable Language Requirement in terms of the Consumer Protection Act - Can we Learn from Past Precedent?" 2012 Obiter 637; Louw "Simply Legal" December 2011 De Rebus 22-25; and Gouws "A Consumer's Right to Disclosure and Information: Comments on the Plain Language Provisions of the Consumer Protection Act" 2010 SA Merc LJ 79).

\section{The exemption provision must be conspicuous}

Section 49(4) requires the fact, nature and effect of the provision to be drawn to the attention of the consumer in a conspicuous manner and form that is likely to attract the attention of an ordinarily alert consumer, having regard to the circumstances. This must be done before the earlier time at which the consumer is required to pay, or enters into the transaction, begins to engage in the activity or enters or gains access to the facility.

The first requirement of the subsection is that the attention of the consumer be drawn to the fact, nature and effect of the provision. Simply put, it means firstly that the consumer must be made aware of the existence (fact) of the provision or notice. Secondly, the consumer must be made aware of the type (nature) of the provision or notice. This seems to require that the consumer must be informed that the provision is a legal term with potential legal consequences (and is not just information or a warning that can be disregarded without consequence) and, if accepted, the provision establishes a legally binding and enforceable contract. Thirdly, the consumer must be made aware that the provision or notice may have the effect of excluding the liability of the supplier - or, stated differently, that the consumer is deprived of a right of redress against the supplier where the consumer has suffered a loss, injury or death as a result of the conduct of the supplier, even where the supplier is negligent.

The second requirement is that the provision must be drawn to the attention of the consumer in a conspicuous manner, meaning in a manner 
that is easy to see or notice or is likely to attract attention (see Wehmeier Oxford Advanced Learner's Dictionary of Current English (2005) 311 for the definition of "conspicuous"). This requirement addresses the question of whether the supplier took reasonable steps to bring the provision or notice to the attention of the consumer. In a document, it may mean that the exemption provision needs to be placed on the very first page and be formatted in a manner that will result in the likelihood of it being noticed, such as putting it in a larger font, in bold lettering and placed in a box with a clear heading and place for a signature at the provision (see De Stadler Consumer Law Unlocked 120-121 for practical guidelines in drawing the fact, nature and effect of exemption provisions to the attention of the consumer).

In a situation where notices are erected, the type of premises, specific layout and other physical characteristics will play a role in determining whether it can be said they have been displayed in a conspicuous manner. Generally such notices will have to appear at various locations in sufficient numbers on the premises of the establishment where the risk might occur and, at the very least, placed at all public entrances. The notices must be visible, large enough to be seen and read, sufficiently well-lit to ensure their visibility to guests arriving after dark, and the establishment must guard against notices becoming obscured by, for example, plant growth. See for instance Naidoo v Birchwood Hotel supra; Hanson $v$ Liberty Group Ltd (4633/2009) [2011] ZAGPJHC 195; and Niemand v Old Mutual Investment Group property Investment (Pty) Ltd (35421/2009) [2012] ZAGPPHC 87.

Drawing the attention of the consumer to an exemption notice can be done in many innovative ways. Placing a notice in the hands of a garden statue or sculpture may help to draw attention to a notice which may otherwise remain unnoticed (see in this regard also the suggestions of Corrada "Liability Waivers in the United States Travel and Adventure Sports Industry" 2006 ITLJ 156-161; and Vrancken and Tait 2008 Speculum Juris 143-145).

The third requirement is that the attention of the consumer must be drawn to the exemption provision before the earlier of the time the consumer is expected to pay for the activity, or the time the consumer enters into the transaction, begins to engage in the activity or enters the facility. The rationale behind this requirement - and its specific formulation - appears to be to provide consumers with the option to change their minds when the exemption provision comes to their attention which must be before any agreement is reached, payment is required or participation takes place. This is to protect the consumer from being placed in a difficult situation where he/she has, for instance, already paid and is only then made aware of the exemption provision and its consequences. For the consumer to opt out or reverse the process at such a point would in many instances just be practically impossible. Prescribing when consumers must be informed is designed to prevent the entrapment of consumers in a situation where turning around is no longer feasible.

This may be quite easy to achieve with online bookings, in that the supplier's website can be set up in a manner that requires the consumer to read and acknowledge that the exemption provision has been read and 
understood before proceeding to make a booking and/or paying any money. Telephonic bookings on the other hand will have to be handled carefully. If a consumer indicates that a booking is required, the supplier must first warn the consumer that an exemption provision will form part of any contract should the consumer wish to make a booking. The supplier will then have to explain the exemption provision to the consumer and get an indication from the consumer that the provision is understood before proceeding with the booking. It may be worthwhile confirming to the consumer via sms or email that the exemption provision has been explained and understood. The message should include the wording of the provision. Such an action, although after the fact, may have significant evidentiary value to show that the exemption provision was explained and that the consumer assented to it. It is clear, for instance, that adventure-sport companies can no longer book an adventure holiday, require payment and then confront the consumer with an exemption provision upon arrival (Naudé 2009 SALJ 509).

Furthermore, for many accommodation establishments, the practical implication of this requirement will be that the notice containing the exemption provision will have to be placed outside the premises on a wall next to or affixed to all entrance doors or gates. Beside the fact that such a notice may detract from the aesthetic appeal of the establishment, it will in all likelihood have a dissuasive potential for prospective guests if the first thing the potential guest sees about an establishment is a conspicuous notice excluding the liability of the supplier for death, personal injury or damages which may befall the guest while staying there. However, this may be the price to be paid for compliance with the Act.

\section{Consumers must have an adequate opportunity to consider the provision}

Section 49(5) of the CPA provides that the consumer must be given an adequate opportunity in the circumstances to receive and comprehend the exemption provision or notice. This means that consumers confronted with an exemption provision must be given sufficient opportunity to read, consider and question any aspects of the provision before deciding whether to assent to it. What this sub-section is trying to prevent is a consumer being pressured into agreeing to the exemption provision.

It may be instructive to consider this requirement in the context of participating in an activity offered by an accommodation establishment. Accommodation establishments often offer extra activities to consumers, including adventure activities such as mountain-biking, horse-riding and game drives. Consumers are usually required to sign an exemption agreement before being allowed to participate in such an activity. The consumer is often required to sign or assent to the exemption provision when the activity has already started (eg, the consumer is already in or on the vehicle en route to the destination or has already been granted access to the facility). It is then extremely difficult for the consumer to opt out of the activity.

Suppliers of the abovementioned services must carefully consider practical ways in which the consumer can be afforded a reasonable 
opportunity to receive and comprehend the exemption provision. It will be sound practice and in line with the requirements of section 49(5) of the CPA to provide consumers with the document containing the exemption provision some time before they are required to sign and submit the document. At the time of checking-in to the accommodation establishment, the consumer can be advised of these additional activities and be provided with a copy of the exemption-provision form applicable to such activities. This will allow the consumer time to consider the provision as well as ample opportunity to question the supplier about the risks involved before even deciding to participate in the activity. Ideally, tourists should be provided with copies of exemption forms where reasonably possible even prior to departing on their holiday by the supplier via the travel agent, tour operator or websites.

\section{Incorporating a section 49(2) scenario}

Section 49(2) of the CPA provides that:

"In addition to subsection (1), if a provision or notice concerns any activity or facility that is subject to any risk -

(a) of an unusual character or nature;

(b) the presence of which the consumer could not reasonably be expected to be aware or notice, or which an ordinarily alert consumer could not reasonably be expected to notice or contemplate in the circumstances; or

(c) that could result in serious injury or death,

the supplier must specifically draw the fact, nature and potential effect of that risk to the attention of the consumer in a manner and form that satisfies the requirements of subsections (3) to (5), and the consumer must have assented to that provision or notice by signing or initialling the provision or otherwise acting in a manner consistent with acknowledgement of the notice, awareness of the risk and acceptance of the provision."

This subsection imposes further prerequisites in certain specific situations in addition to the tests of incorporation contained in subsections 49(3), (4) and (5). Clearly subsection (2) aims to provide for more high-risk situations and therefore imposes these additional requirements when the notice or provision applies to a high-risk situation. Subsection (2) requires firstly, that the supplier must specifically draw the fact, nature and potential effect of that risk to the attention of the consumer in the manner contemplated in subsections $49(3)$ to (5) of the Act. Secondly, the consumer must, in the case of an exemption provision in a written document, assent to the provision by signing or initialling the provision. If the exemption is contained in an exemption notice, the consumer must indicate assent by acting in a manner consistent with acknowledging awareness of the notice, awareness of the risk warned against, and acceptance of the exclusion of liability on the part of the supplier.

Therefore, in the context of subsection 49(2) of the CPA, the consumer must be made aware of two risks. The first is awareness of the existence of a risk or risks contemplated in subsection 49(2). This is the actual risk of, for instance, personal injury. Secondly, the consumer must be made aware of the risk constituted by agreeing to the exemption provision, namely that the consumer's right of redress in the event of a risk contemplated in section 49(2) occurring, has been excluded. 
It should also be noted that in terms of section 58(1), a supplier of any activity or facility that is subject to a risk of unusual character or nature, a risk of which a consumer could not reasonably be expected to have been aware or have contemplated in the circumstances, or a risk that could result in serious injury or death, must draw the fact, nature and potential effect of that risk to the attention of the consumer. This must be done in a form and manner that complies with section 49. It has been pointed out that all "[a]dventure activities, such as cage-diving and bungee-jumping, and facilities, such as gyms, shooting ranges or theme parks, will definitely fall under Section 58(1) because the risk can result in serious injury or death" (Jacobs, Stoop and Van Niekerk "Fundamental Consumer Rights under the Consumer Protection Act 68 of 2008: A Critical Overview and Analysis" 2010 PER/PELJ 378).

\section{Distinguishing between subsections 49(1) and 49(2) scenarios}

It remains to consider the risks covered by subsections $49(1)$ and (2) of the CPA respectively. As already indicated, subsection (2) provides for specific types of risks and it can therefore be said that whatever risk falls outside the ambit of subsection (2) will be covered by subsection (1). For this reason, the guidance provided in subsection (2) is considered to determine the ambit of each subsection.

What is of an "unusual character or nature" is not defined in the Act, but paragraph (a) of subsection (2) refers to a risk that is intrinsic to that activity or facility and which is unusual, being "different from what is usual or normal" (Wehmeier Oxford Advanced Learner's Dictionary of Current English 1622). In other words, where the activity is itself unusual, the provisions of subsection (2) must be complied with because the associated risks will therefore be unusual. The risks may even be self-evident, but because the activity or facility is of an unusual character or nature, the provisions of subsection (2) must apply. It appears that the risks contemplated in paragraph (a) are the risks that may flow from a dangerous activity, and it is dangerous mostly because it is unusual or not normal. The unusual nature of the activity holds the danger or risk and often also the appeal for the consumer.

The probable rationale for this paragraph is that even though the potential for risk may be self-evident, it is considered necessary to draw the attention of consumers to that fact to ensure that they are indeed aware of and fully understand its nature and the potential effect of the risk for themselves. Obvious examples in the context of tourism attractions exist in the cases of bungee-jumping or white-water rafting. The risks for participants are fairly obvious but must be warned against nonetheless.

Paragraph (b) of subsection (2), in turn, provides for the situation where the risk is not evident and risk would not normally be associated with the activity or facility as it is a risk of which a consumer could not reasonably be expected to have been aware, or which an ordinarily alert consumer could not reasonably be expected to have contemplated in the particular circumstances. However, the supplier of the activity or facility is aware of the 
potential risk, or is at least in a position to foresee the risk because of the experience or specialized knowledge that the supplier has. The supplier therefore will have to draw the attention of the consumer to the fact, nature and potential effect of the risk (which the consumer cannot foresee but the supplier should or does foresee) in the prescribed form.

Paragraph (c) of subsection (2) pertains to an activity or facility that could cause serious injury or death. As subsection (2) is worded, where there is an unusual risk or one that cannot be reasonably foreseen (even if the risk is such that it will not result in serious injury or death), the supplier must comply with section 49(2). Furthermore, there must be compliance with section 49(2) when any risk exists, whether of unusual character or nature or not and whether or not it is reasonably foreseeable by the consumer, which may result in serious injury or death. Understood in this manner, there is a distinction between the different paragraphs. However, there remains a significant overlap between the situations covered by paragraph (c) and the other two paragraphs.

This interpretation does place a significant responsibility on the supplier to carefully consider the potential risks (and the potential seriousness) of the facilities and activities provided, in order to ensure compliance with section 49, including section 49(2). Failure to do so can be extremely costly.

In implementing section 49 , the supplier will have to consider the context within which the exemption provision or notice will be used and the type of risk the consumer will be exposed to. This will determine the exact prerequisites with which the supplier must comply to validly make use of, and enforce, an exemption provision. If the provision or notice is used in a normal-risk context, then the requirements of subsection (1), incorporating the requirements of subsections (3) to (5), with which must be complied. If the notice is used in a high-risk scenario, the supplier must comply with the requirements of subsection (1), also incorporating the requirements of subsections (3) to (5), as well as the additional requirements as provided for in subsection (2).

A problem that suppliers (such as suppliers of tourist-accommodation establishments and tourist attractions) may face in implementing the provisions of section 49 , is in trying to determine whether it is necessary to comply with the requirements of subsection (2) over and above the other requirements of section 49 . It may well mean that such establishments must comply with both sets of requirements depending on the context. A hotel may make use of a general exemption provision which is aimed at excluding liability for normal-risk. This provision will form part of the contract concluded with the consumer at the time of booking or registration. This provision must then comply with the requirements of subsections $49(1)$ and (3)-(5) of the CPA. However, the hotel may also make use of a provision or notice in respect of particular activities at the establishment that may require the application of subsection 49(2) and its requirements over and above the requirements of subsections $49(3)-(5)$. 


\section{Substantive control measures - sections 48 and 51}

\section{Section 51}

Section 51 contains a blacklist of terms that a supplier is prohibited from including in a consumer contract. Specifically section 51(1)(c)(i) prohibits a provision which purports to limit or exempt a supplier of goods or services from liability for any loss attributable to the gross negligence of the supplier.

Excluding liability for death, injury or damage to or loss of property which is caused by the gross negligence of the supplier is no longer possible where the supplier-consumer relationship is subject to the CPA.

\section{Section 48}

Section 48 of the CPA provides for content control of consumer agreements in that it contains a general prohibition against unfair, unreasonable and unjust terms in consumer agreements (see the insightful discussion of Naudé 2009 SALJ 514-519 on the role of section 48 in controlling the content of contracts, as well as Hawthorne "Public Governance: Unpacking the Consumer Protection Act 68 of 2008" 2012 THRHR 361-363). For purposes of the current discussion, section 48(1)(c) specifically prohibits a supplier from requiring a consumer to whom goods or services are provided at the direction of the consumer, to waive any rights, assume any obligation, or waive any liability of the supplier in terms that are unfair, unreasonable or unjust, or impose any such terms as a condition of entering into a transaction. What constitutes unfair, unreasonable or unjust terms is not defined, but subsection 48(2) provides guidance as to their interpretation. (The regulations to the CPA also assist by providing a long list of grey terms in regulation 44(3) presumed to be unfair, unreasonable or unjust.)

Section 48(2)(d)(i) specifically provides that, if a transaction or agreement was subject to a term, condition or notice contemplated in section 49(1) and the term, condition or notice is unfair, unreasonable, unjust or unconscionable, then the agreement or transaction consequently will be unfair, unreasonable or unjust. This section, despite its rather circular nature, relates to the substantive (un)fairness of the exemption provision itself and also, arguably, to the potential substantive (un)fairness in enforcing an exemption provision in a particular situation. Thus even if there is full compliance with the formal prerequisites of section 49, the exemption provision or notice in its substantive form or application may be unfair, unreasonable and unjust (see Barkhuizen $v$ Napier supra par 56; and Naidoo $v$ Birchwood Hotel supra par 45 , as well as the elucidating discussion by Hawthorne 2012 THRHR 350-352 on the proper approach to constitutional challenges to contractual terms as formulated by the Constitutional Court in Barkhuizen v Napier supra par 56).

In Naidoo $v$ Birchwood Hotel (supra), which matter was decided prior to the CPA coming into operation, the Court held that enforcing the exemption provision that existed between the parties would have been unfair and unjust because it would have had the effect of denying the consumer access to the courts. The Court came to this conclusion in the specific circumstances of 
the case where the consumer sustained his injuries in the process of exiting from the hotel. In this regard the Court stated (par 53):

"To enter and egress is an integral component of his stay. A guest in a hotel does not take his life in his hands when he exists through the hotel gates. To deny him judicial redress for injuries he suffered in doing so, which came about as a result of the negligent conduct of the hotel, offends against notions of justice and fairness."

Partaking of a normal activity like taking a shower, switching on a kettle or television set, exiting or entering through a gate or door are activities that can "by no stretch of the imagination be considered dangerous" (Naidoo $\mathrm{V}$ Birchwood Hotel supra par 45) and therefore it would be unfair to allow the supplier to exclude liability for death or personal injury resulting from the negligent actions of the supplier.

Section 48(2)(d)(ii) provides that, if the fact, nature and effect of the provision or notice contemplated in section 49(1) was not drawn to the attention of the consumer as prescribed by the section - then the transaction, agreement, term, condition or notice is unfair, unreasonable and unjust. Non-compliance with the tests of incorporation provided for in section 49 make the use of the exemption provisions unfair, unreasonable and unjust. Section $48(2)$ (d)(ii) appears to be more a test of incorporation than a measure of content control. Section 48 has been criticized for not just providing content control but for confusing and conflating other forms of control with content control (Naudé 2009 SALJ 518).

\section{Regulation 44(3)(a)}

The regulations made in terms of the Act provide important guidance regarding what will be considered unfair, unreasonable and unjust terms. Regulation 44 contains a so-called "grey-list" of contract terms that are presumed to be unfair, unreasonable and unjust for purposes of section 48 of the CPA. Regulation 44(3)(a) in particular will have a significant impact on an exemption provisions. The provision provides that:

"A term of a consumer agreement subject to the provisions of subregulation

(1) is presumed to be unfair if it has the purpose or effect of -

(a) excluding or limiting the liability of the supplier for death or personal injury caused to the consumer through an act or omission of that supplier subject to section 61(1) of the Act."

Thus, the inclusion of a term in a contract which excludes liability for death or personal injury is presumed to be unfair. A supplier, wishing to rely on the protection of an exemption provision in the event of a claim resulting from the death or personal injury of the consumer, will bear the onus to prove that the exemption provision is fair. This presumption will present the supplier with a significant challenge indeed. It is difficult to foresee how a supplier can argue that it is fair to exclude the supplier's liability for negligence when the consumer undertakes "an activity that could by no stretch of the imagination be considered dangerous" (Naidoo v Birchwood Hotel supra par 45). The consequence of this provision may well be that provisions or notices excluding the liability of a supplier for the death or personal injury of 
a consumer sustained during participation in normal-risk activities will not be considered fair for purposes of section 48 of the CPA - a position seemingly supported by the courts if one considers the views expressed in Johannesburg Country Club v Stott (supra) and Naidoo v Birchwood Hotel (supra).

The likelihood is greater that exemption provisions in respect of high-risk activities (s 49(2) scenarios) will more readily be considered fair because these activities may often entail a considered decision by the consumer to expose himself/herself to the dangerous activity. Where a supplier, for example a hotel, offers certain high-risk activities such as exposure to wild animals, then the supplier is more likely to succeed in proving that the exemption provision is indeed fair in the specific circumstances. This is an important consideration since adventure tourism has become one of the fastest-growing niche markets in international tourism, and South Africa markets itself as an adventure destination (see George Managing Tourism in South Africa (2007) 346-350). Tourists seek adventure and with adventure come risk. It may well be argued that suppliers should be allowed to protect themselves against the risks that may result from even the slightest negligence. This is exactly the point of Marais JA in his separate judgment in Johannesburg Country Club v Stott (supra par 15), when he stated:

"Slight negligence may have no consequences in once case; in another it may have catastrophic consequences. Death is but one of them. I would need considerable persuasion before concluding that a party to a contract who wishes to protect himself or herself against the possibility that a moment's inattention may result in an enormous civil liability for damages, is to be prohibited by law from doing so despite the other party's willingness to contract on that basis."

But, of course, the supplier will also have to establish that there has been complete compliance with section 49 of the CPA, particularly since a significant part of the supplier's case that the exemption provision is fair will rely on the consumer making an informed decision to participate in the highrisk activity. It may be against the interests of justice and fairness if a party is prevented by law from protecting himself/herself from civil liability despite the other party's willingness to contract on that basis, particularly in the context of a high-risk situation and where there has been full compliance with the tests of incorporation.

A further aspect of regulation 44(3)(a) to be considered is the fact that the regulation is only relevant to exemption provisions applicable in the event of death or personal injury, and not to damage or loss of property. Thus an exemption provision incorporated into a contract with a consumer must be presumed unfair in so far as it excludes liability for death or personal injury, but not if it excludes liability for damage or loss to property.

\section{Effect of non-compliance}

Section 52(1)(a), read with section 52(3), provides that, if a provision or notice fails to comply with the requirements of section 48 , the court may declare such provision or notice to be unfair, unreasonable or unjust and may make such other order as is deemed reasonable in the circumstances. 
In effect an exemption provision or notice found to be in violation of section 48 will be declared void and severed from the contract.

Section 52(4)(a)(ii) of the CPA provides that in proceedings before a court where it is alleged specifically that any agreement, term or condition of an agreement, or notice does not comply with the applicable requirements of section 49 of the Act, a court may sever such provision or notice from the agreement or declare it to have no force or effect.

Naudé (2009 SALJ 509) argues that to require a court to pronounce a term or notice to be of no force and effect is to ignore the limitations the judicial process holds for consumers, particularly in view of the time, cost, risk and effort factors. The challenges faced by tourist consumers, especially international tourists, are even greater. Naudé (2009 SALJ 509-510) suggests that it would have been preferable had section 49 stated that noncompliance with the requirement of section 49 would prevent the supplier from relying on the term or notice, which would mean the court would only need to be approached in the event of a dispute. Although this reasoning is agreed with, it is probably not often that a supplier would use such an exemption provision or notice only to concede that it does not comply with the requirements of section 49. Thus, judicial adjudication would in any event be required, not only to pronounce on whether the term or notice was in plain language but also in respect of the other incorporation requirements, not to mention questions relating to content control.

\section{$4 \quad$ Conclusion}

Hawthorne (2012 THRHR 370) has stated that "[t]here is no doubt that the introduction of the Consumer Protection Act has introduced a shift from a freedom-orientated approach to consumer contracts to a fairness-orientated approach ..." The CPA has changed the rules of the game and has introduced both substantive content control and tests of incorporation for using exemption provisions.

The tests of incorporation place a significant burden on suppliers to ensure that the exemption provision is drawn to the attention of the consumer according to the dictates of section 49. Once these stringent requirements have been met, the exemption provision is subjected to a fairness test. Whether the exemption term or notice is fair and reasonable, or whether the enforcement of a seemingly reasonable and fair term or notice is indeed fair and reasonable, will depend on each situation. However, two aspects will play a significant role. These are firstly, whether one is dealing with exclusion of liability for death or personal injury. If this is the case, then the exemption provision is presumed unfair and the supplier then has the burden to prove that the exemption provision or notice is fair. This brings into play the second factor, namely whether one is dealing with a situation of high or normal risk. It is submitted that a supplier will have an exceptionally difficult task to discharge the burden to prove that excluding liability for death or personal injury of a consumer participating in normal-risk activities, is fair. In a situation where one is dealing with a high-risk scenario to which the consumer has consented after complete compliance with the section 49 
requirements, a case may well be made that excluding liability in such a situation is fair.

What is certain is that the CPA has brought about significantly greater protection for consumers in the context of the use (and abuse) of exemption provisions.

Mark Tait and Stephen Newman Nelson Mandela Metropolitan University, Port Elizabeth 